\title{
The Discovery of Slowness in Music
}

\section{Citation}

Rehding, Alexander. 2015. The Discovery of Slowness in Music. In Thresholds of Listening:

Sound, Technics, Space, ed. Sander van Maas. New York: Fordham UP.

\section{Published Version}

http://fordhampress.com/index.php/threshods-of-listening-cloth.html

\section{Permanent link}

http://nrs.harvard.edu/urn-3:HUL.InstRepos:32785050

\section{Terms of Use}

This article was downloaded from Harvard University's DASH repository, and is made available under the terms and conditions applicable to Open Access Policy Articles, as set forth at http:// nrs.harvard.edu/urn-3:HUL.InstRepos:dash.current.terms-of-use\#OAP

\section{Share Your Story}

The Harvard community has made this article openly available.

Please share how this access benefits you. Submit a story.

\section{Accessibility}




\section{The discovery of slowness in music}

Alexander Rehding

\section{Once upon a time...}

Imagine the slowest music. ${ }^{1}$ Those trained in classical western music might spontaneously think of Franz Schubert's proverbial "heavenly lengths," perhaps the Adagio from the String Quintet, or slow movements from Bruckner or Mahler Symphonies; those more interested in contemporary compositions might think of works by Morton Feldman, Toru Takemitsu or Henryk Górecki. Now imagine music that is much slower still. This kind of slowness is perhaps best described by one of the Grimm Brothers' less well-known fairy tales, the Little Shepherd Boy. When asked by a King to explain eternity, the shepherd boy replies:

[There is a] Diamond Mountain in Lower Pomerania, and it takes and hour to climb it, an hour to go around it, and an hour to go down into it. Every hundred years a little bird comes and sharpens its beak on it, and when the entire mountain is chiseled away, the first second of eternity will have passed. ${ }^{2}$

The shepherd boy's story relies on two aspects that characterize the exceedingly slow passing of time: an excruciating low density of events that mark time, and an impossibly long duration as the summation of these events, which in this story is tantamount to eternity.

\footnotetext{
${ }^{1}$ With thanks to Joseph Auner, Kiene Brillenburg Wurth, Michael Scott Cuthbert, Mike Einziger, Christopher Hasty, Branden Joseph, Brian Kane, Thomas F. Kelly, Frank Lehman, Matthew Mugmon, Susan Rankin, and Gregory Spears. 2 Jack Zipes, tr., The Complete Fairy Tales of the Brothers Grimm, 3rd ed. (New York: Bantam, 2003), 468.
} 
This definition, to be sure, does not hold water as far as any philosophical approaches to eternity are concerned. ${ }^{3}$ But what makes the shepherd boy's definition so ingenious-and the reason he is amply rewarded by the king-is that he gives a definition which not merely states the obvious point, as any philosopher would have done, that eternity is infinite and that this dimension transcends the capacity of our imagination. Rather, it breaks it down into an array of the most concrete terms that allow us to grasp every element of his story and still makes it impossible to get our mind around the concept fully. Crucially, the shepherd's explanation relies on events that mark the passing of time, it is just that the events move at such slow speed that the adjective "glacial" seems positively inflationary. In a word, it allows us to experience the impossibility of grasping the whole. The fact that this impossibly long period of time captures only the first second of eternity, in a process that may or may not be open-ended, is only the icing on the cake.

The shepherd boy's endeavor to convey the awe-inspiring incomprehensibility of eternity relies on the concept of the sublime. This is not surprising, since the paragon of what Kant called the "mathematical sublime" is infinity. ${ }_{4}^{4}$ It seems, though, that the shepherd boy followed Johann Sulzer-more so than the influential Kantian tradition. ${ }^{5}$ Sulzer was

${ }^{3}$ The philosophical authorities cited most frequently in connection with the concept of eternity are Aristotle or Augustine. For them, eternity describes an existence outside of time. Even the tiniest change that happens to the eternal substance threatens that fragile state, for it implies the possibility of further changes and ultimately that its existence could be finite. (One might argue, in the shepherd's defense, that his concept is potentially openended-if we posit an infinite number of mountains his definition could be salvageable. But this is obviously clutching at straws.)

${ }^{4}$ The "Analytic of the Mathematical Sublime" is included in Sections 125-127 of Kant's Third Critique. See Immanuel Kant, Kritik der Urteilskraft (Frankfurt am Main: Suhrkamp, 1968), 169-184.

${ }^{5}$ As has been widely discussed, Kant's sublime consists in two parts: the unpleasant realization that our imagination is unable to grasp a phenomenon in its totality is followed 
particularly concerned about the immediate psychological impact of the sublimeastonishment—and the most effective modes of representation:

If we are told that God created the world ex nihilo, or that God rules the world by His Will, we experience nothing at all, since this lies totally beyond our comprehension. But when Moses says: 'And God said, let there be light; and there was light,' we are overcome with astonishment because we can at least form some idea of such greatness; we hear to some extent words of command and feel their power; and if we are made to see instead of the mere Divine Will some empirical symbol of it: ... We must have a yardstick by which we seek to measure the extent of the sublime, even if unsuccessfully. ${ }^{6}$

It is possible to find fault in Sulzer's uncomplicated approach to representation, but it is worth remembering that Sulzer, unlike Kant, makes space for the sublime in art. ${ }^{7}$ In order for the sublime to be conveyed effectively, Sulzer contends, it must allow its audience to imagine the unimaginable. ${ }^{8}$ It must be given at least a brief glimpse, an "empirical symbol," of that which they cannot comprehend, and that is what the shepherd boy so admirably accomplished.

by a triumphant affirmation of the greater power of reason. This second part is much less explicitly theorized by Sulzer.

${ }^{6}$ Sulzer, "Erhaben," from Peter LeHuray and James Day, Music and Aesthetics in the Eighteenth and Early-Nineteenth Centuries (Cambridge: Cambridge University Press, 1981), 138-9. Sulzer follows biblical tradition in regarding Moses as the author of the Pentateuch. ${ }^{7}$ This has been a problem for critics ever since. Many of them are at pains to explain that Kant could well have allowed for a sublime in art.

${ }^{8}$ To be sure, Kant also introduces images that try to make the unimaginable approachable, such as the "starry skies above us," but the Kantian version of the sublime has a strong sense of the unrepresentability of the sublime, epitomized in Kant's much-discussed reference to the sublimity of the second commandment. 
In the context of postmodernism this more theatrical approach to the sublime has made something of a comeback. ${ }^{9}$ The postmodern sublime, as Jean-François Lyotard explains it, no longer nostalgically wallows in the problem of representation, but rather stages its very un(re)presentability ${ }^{10}$ :

The postmodern would be that which in the modern invokes the unpresentable in presentation itself, that which refuses the consolation of correct forms, refuses the consensus of taste permitting a common experience of nostalgia for the impossible, and inquires into new presentations—not to take pleasure in them, but to better produce the feeling that there is something unpresentable. ${ }^{11}$

Lyotard's approach underlines that the postmodern does not define a historical period but a mode of thinking - and of experimenting in art. For him, the postmodern and the sublime are interchangeable terms: both are characterized by the mise-en-scene of their own impossibility. This brings us back to the shepherd's boy and the broader question of a slowness in music so vast that it exceeds our capacity to process it, a music moving so slowly that we can only begin to contemplate the gigantic temporal dimension that it spans.

\footnotetext{
${ }^{9}$ This is not to say that interest had ever significantly ceased: a continuing line can be drawn from Kant and Schopenhauer via Nietzsche and Wagner to Adorno. Not least owing to the use of the sublime under the National Socialists, however, the sublime had become an extremely touchy subject in the post-war era. Christine Pries, Übergänge ohne Brücken: Kants Erhabenes zwischen Kritik und Metaphysik (Berlin: Akademie-Verlag, 1995), has explored this history in Germany.

${ }^{10}$ Lyotard explores these terms in "Representation, Presentation, Unpresentable," The Inhuman: Reflections on Time (Cambridge: Polity Press, 1991), 119-128.

${ }^{11}$ Jean-François Lyotard, The Postmodern Explained (Minneapolis: University of Minnesota Press, 1993), 15.
} 
This is the kind of slowness that I am interested in. It is music so slow that we need to renegotiate its fundamental terms. The two slow pieces of music that I am going to discuss in some detail here, the Halberstadt John Cage Organ Project (2001) and 9 Beet Stretch (2002), are not musical works in any ordinary sense. To be sure, they started out that way, but in the performances that I am going to discuss they last forever, or at least it seems that way. In fact, it is not even obvious that performance is the correct term, since no performer in the ordinary sense is involved: "version," “adaptation," "installation" might be more appropriate terms to describe this situation. For simplicity's sake, I will usually refer to them as "pieces." Apart from the issues about temporality that these pieces raise, as we shall see, they also pose interesting wider questions about the ontology of the work of art.

It is no coincidence that pieces of great slowness-and its constant companion, lengthwere created around the turn of the millennium, doubtless the most important event in the psychological history of time in our lifetime. The millennium is in principle an arbitrary marker, but since it highlights the cyclical nature of time, writ large, it invites reflections on the passage of time. ${ }^{12}$ This is perhaps most vividly reflected in the "Clock of the Long Now," devised by Danny Hillis and first displayed in the Science Museum in London. Hillis explained his idea:

I think it is time for us to start a long-term project that gets people thinking past the mental barrier of the Millennium. I would like to propose a large (think Stonehenge)

\footnotetext{
${ }^{12}$ It is surprising that there is relatively little literature on this. See, for instance, Time: Perspectives at the Millennium (The Study of Time X), ed. Marlene P. Soulsby and J. T. Fraser (Westport CT and London: Bergin \& Garvey, 2001), and Aleida Assmann, "Denkmäler in der Zeit: Vom Sinn und Unsinn der Gedenkjahre," Schiller-Jahrbuch 44 (2000), 298-302.
} 
mechanical clock, powered by seasonal temperature changes. It ticks once a year, bongs once a century, and the cuckoo comes out every millennium. ${ }^{13}$

The Clock of the Long Now began its work on December 31, 1999, and is supposed to run for 10,000 years. It really does not matter, as the novelist Michael Chabon has pointed out, whether the clock will really run for that amount of time or indeed whether humanity will witness the end of this long period: what matters is that it helps us conceptualize the imagined connection between us and the most distant past and future. ${ }^{14}$ As in Sulzer's example, it is the concreteness of the material object, the "empirical symbol," that allows us to begin to grapple with concepts that would otherwise lie beyond our comprehension.

In Hillis's description too we notice again the connection between extremely long duration and an exceptionally slow pace of the events marking the passing of time, not dissimilar from the shepherd boy's narration. To be sure, both pace and duration obviously operate in the temporal dimension, and overall duration is the totality of the succession of temporal events. But beyond that, there is no inextricable connection between pace and duration, between speed and time span: there is no intrinsic reason why the clock should not tick every second over 10,000 years $(315,576,000,000$ times $)$, just as there is no inescapable reason why a very slow piece of music could not also be relatively short-other than the psychologically satisfying correlation between a slow pace of events and vast expanses of

\footnotetext{
${ }^{13}$ Stewart Brand, The Clock of the Long Now: Time and Responsibility (New York: Basic Books, 1999), 2.

${ }^{14}$ Michael Chabon, "The Omega Glory," in Manhood for Amateurs: The Pleasures and Regrets of a Husband, Father, and Song (P.S.) (New York: Harper, 2009), 253-259. This essay was written under the impression of the "Clock of the Long Now."
} 
time. By rarefying the pace of events marking time we obtain a more palpable sense that time is stretched out and effectively passes more slowly.

In the field of music, all these millennial projects are concerned with great lengths, and slowness is one important way of achieving temporal length, but far from the only one. Another important millennial composition, Jem Finer's Longplayer, was begun on December 31, 1999, and is to last for exactly 1000 years (at which point it starts again from the top). ${ }^{15}$ This musical project generates its awe-inspiring length not by means of exceptional slowness but with an algorithm that calculates ever-changing patterns on the basis of an original composed sequence played on a series of (computer-simulated) Tibetan singing bowls.

What matters in these millennial pieces, no matter how their sublime lengths are generated, is the contemplation of the long time spans they articulate. The "Long Now" describes the imagined connection between the present and the most distant past or future. Not coincidentally, the concept of the "Long Now" was coined by the composer Brian Eno. ${ }^{16}$ As a composer, Eno was aware that music, as the temporal art par excellence, had a big role to play in this discourse. A taste of Lyotard's postmodern lurks behind this paradoxical term: as an experiential unit, the very idea of the "now" is one of the greatest challenges of the philosophy of time. ${ }^{17}$ "Now" is perhaps best understood as a forever fleeting point in time with no extension at all, impossible to capture and precisely the

\footnotetext{
15 See http://longplayer.org/, accessed May 28, 2010.

16 Brian Eno, "The Big Here and the Long Now" http://longnow.org/essays/big-here-longnow/ accessed May 28, 2010.

17 William James's psychological approach is particularly pertinent here, see his Principles of Psychology (New York: Cosimo, 2007).
} 
opposite of the long duration. Extended-or rather, distended-moments of presence, during which "duration turns limp,"18 as Lyotard shows in his late reflections on Augustine's Confessions, are removed them from everyday temporality and move the self to a different experiential realm. This is the kind of liminal aurality that we are concerned with here. As we shall see, it is precisely this problematic "long now" that assumes a position center stage in the Halberstadt John Cage Organ Project.

\section{The Halberstadt John Cage Organ Project}

Halberstadt, a small town in the middle of Germany, made it into the international news in 2000, when it announced the start of their rendition of John Cage's $\operatorname{Organ}^{2} / A S L S P$. (ASLSP was originally written for piano, in 1985, then revised and authorized for organ as $\left.\operatorname{Organ}^{2} / A S L S P, 1987.\right)$ The title of the piece is both an abbreviation of As SLow aS Possible and reminiscent of the word "lsp," which is found in the final paragraph of James Joyce's Finnegans Wake, a book that Cage greatly admired and from which he repeatedly drew inspiration. ${ }^{19}$

The score of this piece uses the symbols of conventional notation but has no time signature, bar lines, or tempo marking. Note heads indicate pitch but rhythms are not given in the conventional manner. Instead, the distances between note stems, which are very precisely placed, indicate the relative duration of each sonority in each hand. Furthermore,

\footnotetext{
18 Jean-François Lyotard, The Confession of Augustine (Stanford, CA: Stanford University Press, 2000), 18. Lyotard explores how these languid extended moments assume a theological, sexual, and ontological dimension.

${ }^{19}$ See John Cage, ASLSP for piano or organ solo (New York: Henman, 1985).
} 
beginnings and endings of individual pitches are indicated by means of a complex system of black and white note heads as well as special symbols. Different recorded performances of the work take between five and seventy minutes. Once we step outside the realm of recordings, with their own temporal limitations, noteworthy "live" performances include Diane Luchese's 2009 organ performance in Towson (which lasted almost 15 hours) and Joe Drew's 2008 piano performance, which lasted a whole 24 hours.

As an ironic aside, John Cage originally composed $A S L S P$ as a commission for a piano competition. Needless to say, the piece could not be further removed from the flashy virtuosity of competition pieces. An element of random is built into the form of the piece, which consists of eight short sections: Cage specifies in the score that the sections can be played in any order, but one should be left out, while another one should be played twice. When Cage also authorized the adapted version of this piece for organ in 1987, it was this later adaptation that opened up completely new temporal dimensions for the performance of this piece: for the piano, the slowness of performance is relatively constrained by the mechanics of sound production on the piano with its relatively fast decay, while on the organ the sound can in principle be sustained indefinitely. By authorizing the organ version, Cage counteracted the peculiarly ephemeral materiality of musical sounds, which writers throughout history have lamented or celebrated. The philosopher Hegel—a name not often mentioned in the same breath as Cage-probably put it most poetically when he 
defined the tone as "ein Daseyn, das verschwindet, indem es ist." —an existence that disappears by being. ${ }^{20}$

In the Halberstadt rendition, at any rate, the disappearance takes a long time: the piece is to last 639 years. The Halberstadt performance is widely (if only with some hedging) hailed as "the longest concert in the world." 21 The span of time is symbolic: according to the seventeenth-century music theorist and composer Michael Praetorius, the cathedral in Halberstadt housed the first organ with the semitonal keyboard arrangement that we are now used to. As the organizers of the Halberstadt John Cage Organ Project proudly claim, with a good dose of hyperbole, this keyboard layout represents the cradle of modern music. $^{22}$ This historic organ had been built in 1361, that is 639 years before the year 2000 . To mark this important date with respect to the new millennium, this commemorative length was chosen.

As the temporal durations unfold, a new organ is installed pipe by pipe. The piece began, on September 5, 2001, the composer's birthday, with a year and half's worth of rests, before

${ }^{20}$ Georg W. F. Hegel, Enzyklopädie der philosophischen Wissenschaften im Grundrisse (Hamburg: F. Meiner, 1959), 369. See Friedrich Kittler, "Real Time Analysis, Time Axis Manipulation," in Draculas Vermächtnis: Technische Schriften (Leipzig: Reclam Leipzig, 1993), 182. Hegel uses a similar formulation in his Ästhetik (Frankfurt am Main: Suhrkamp, 1970), III: 134.

${ }^{21}$ Ulrich Stock, "Die eingefrorene Zeit," Die Zeit, January 8, 2006. The Project's own website claims, falsely, to be the "slowest and longest piece of music in the world." http://www.john-cage.halberstadt.de/new/index.php?seite=dasprojekt\&l=e , accessed May 28, 2010.

${ }^{22}$ http://www.john-cage.halberstadt.de/new/index.php?seite=dasprojekt\&l=e, accessed May 28, 2010. 
the first sonority was heard. ${ }^{23}$ At this level of slowness, each sonority, each event, lasts for months or years. Each change of sonorities, timed so as always to fall on the fifth of the month, is a major event that attracts wide public attention. There is no human performer in an ordinary sense: the keys of the organ are held down by simple weights attached to them.

This performance poses some interesting problems: pitches and the relative durations in this rendition are preserved with considerable accuracy-in certain analytical traditions of philosophy, these are the key traits that mark the ontology of the work of music in performance. ${ }^{24}$ And yet, one could make a reasonable claim that this performance problematizes the concept of the musical work, for the simple reason that it is humanly impossible to hear the piece from beginning to end. Like the shepherd's boy, we can apprehend all the parts of the piece, but the totality of it exceeds the limits of our capacity of our imagination to relate the different parts to each other experientially.

The organizers at Halberstadt argue, not implausibly, that John Cage would have approved of this rendition of his composition. They view this extremely slow performance as a "musical apple tree," a "symbol of confidence in the future."25 (The image of the apple tree alludes to a popular German aphorism usually ascribed to Martin Luther: "If I knew that the world were to end tomorrow I would plant an apple tree today.") And similarly, in

${ }^{23}$ Stock, "Seiner Zeit voraus," points out that the organizers forgot to adjust for the delayed start and began the first sonority a year before its time. The performance will be readjusted in 2013, to end-correctly-in 2640.

${ }^{24}$ Nelson Goodman's influential Languages of Art: An Approach to a Theory of Symbols (Oxford: Clarendon Press, 1969) is probably the most famous of these.

${ }^{25} \mathrm{http} / / /$ www.john-cage.halberstadt.de/new/index.php?seite=dasprojekt\&l=e , accessed May 29, 2010. 
Chabon's reflections on the "Clock of the Long Now," these bold, longevous objects came to inspire optimism and faith in the future.

We should unpack these expressions of optimism a little bit, as they seem to be getting ahead of themselves. In the philosophical traditions ${ }^{26}$ of the sublime, the concept usually contains a two-phase mechanism: the sublime is typically figured as a mixed emotion in which initial displeasure, in the face of incomprehensible magnitude, which couldfiguratively or literally—crush the individual, gives way to a sense of affirmation of the self, brought about by virtue of reason's enduring ability to withstand this sensory overload. In his inspiring ebullience in the face of the "Long Now," Chabon leaps straight to the second phase, the triumphant affirmation of the self as a rational being. The clock allows him to consider this enormous time span from the outside, as it were, to contemplate its meaning without getting caught up in the durational aspects of this enormous temporal span.

In musical terms, however, things are not quite so obviously rosy: while the "Long Now" allows for a conceptual bridge in the imaginary realm from the present to the most distant future, the moment-to-moment connections in music are under strain. The music has been slowed down to such an extent that the "Musical Now,"27 to borrow a category from Christopher Hasty, is under threat: the events that help us perceive the passage of time in music are so extremely stretched out that our temporal perception is given very little to go by. Paradoxically, in perceptual terms, the constantly unchanging sound is the equivalent of

\footnotetext{
26 This is somewhat simplified: the sublime has strands in French, British and German philosophy, which all differ from each other. Here the tradition that matters most is the Kantian and post-Kantian tradition, which is also the one that Lyotard picks up again in the context of the postmodern. A recent summary of different strands of the sublime can be found in Philip Shaw, The Sublime (New York: Routledge, 2006).

${ }^{27}$ Christopher Hasty, Rhythm as Meter (Oxford: Oxford University Press, 1997), 76-78.
} 
silence-it is marked by a lack of sonic events that would capture our attention. ${ }^{28}$ In the realm of music, it seems, the "Long Now" does not make the connections between past and future more manifest but rather complicates them.

Lyotard, who takes Barnett Newman's essay, "The Sublime is Now," as the touchstone for a reflection on the sublime and the avant-garde, cautions that the outsize proportions with which the sublime operates make questionable precisely the assurance ascertained in Newman's title: is "now" the sublime? What exactly is "now" if one event can last years and months? Is it happening? ${ }^{29} \mathrm{~A}$ listener might have legitimate fear that the next event, a new marker for the "now" — the "It happens that," as Lyotard calls it—may never occur. It is precisely this uncertainty that makes the pain and pleasure that characterizes the sublime. "What is terrifying," Lyotard explains, "is that the It happens that does not happen, that it stops happening." ${ }^{30}$ The sounding silence of the $\operatorname{Organ}^{2} / A S L S P$ might continue indefinitely; an ever-lasting "now" loses all meaning. ${ }^{31}$

This silence may pose an aesthetic challenge-of a rather Cagean kind..$^{32}$ The effect of the "sounding silence" of the Halberstadt John Cage Organ Project is that it reverses in many ways our normal relationship with the musical object: the music does not move through us,

\footnotetext{
28 Ibid., 78.

${ }^{29}$ Lyotard, "The Sublime and the Avant-Garde," The Inhuman, 89-107.

30 Ibid., 99.

31 The dates of the changes of sonorities are well known, and constitute well-attended events. In some ways, it is a pity that the next sonic event is so well advertised in advance: in this way the duration of the musical now becomes less suspenseful.

32 In fact, Cage comments on silence, in his "Lecture on Something," a reflection on Morton Feldman's music, in broadly corresponding terms (with a portion of Zen Buddhism thrown in, to be sure). See his Silence: Lectures and Writings (Middletown, CT: Wesleyan University Press, 1973), 135. See also Kiene Brillenburg Wurth, Musically Sublime: Indeterminacy, Infinity, Irresolvability (New York: Fordham University Press, 2009), 130-131.
} 
but we move through the music. I mean this in a very literal sense: the spatial dimension of this performance, its situatedness inside the church, allows the listener to wander through the immutable sonorities and explore this cheerfully static music that becomes, in the absence of a perceptible temporal dimension, fulfilled in the spatial realm. ${ }^{33}$

This brings us to the central question that I am concerned with here: What kind of dimension is it where the experience of time all but breaks down? Is this dimension really spatial in any meaningful sense? There is a sense that this spatial dimension behind and beyond the temporal dimension is born out of an awkwardness, or rather, for want of a better expression. As is often pointed out, our vocabulary breaks down when it comes to describing temporality, and we invariably have to resort to spatial metaphors. The spatial realm, after all, is the dimension in which we can comprehend, where we can "get a handle" on the sublime. ${ }^{34}$ The spatial dimension allows a comparative perspective where we do not take in the sublime in its own right, but rather compare its size to something more manageable. This possibility is always given, but it can sidestep the psychological element of the dizzying sublime by reaching for safe ground.

So, is our imagination not large enough to comprehend what might be found where temporality ends?-One cannot help but think of Wagner's Zum Raum wird hier die Zeit"Here time turns into space," which is what Gurnemanz contends at the beginning of the

${ }^{33}$ It is useful to remember here the fundamental distinction of the primary senses: vision is related to the spatial domain, and hearing to the temporal, and likewise, objects-to-be-seen remain, whereas objects-to-be-heard disappear. (See also Wolfgang Welsch, Ästhetische Grenzzüge, 247, who has recently drawn attention to this fundamental distinction.) The idea of extreme slowness that we are working with here breaks down the certainties associated with these boundaries.

34 See fnn. [63] and [64] below. 
transformation music of Act I of Wagner's Parsifal. But, we should ask, is the dimension beyond temporality necessarily spatial? Hans-Jürgen Syberberg offers one answer in his justly celebrated 1982 video production of Parsifal 35 that takes this conundrum seriously and manages to transplant the sense of sublimity into the spatial domain: he sets Act I in a mountainous landscape that emerges gradually as an enormous version of Wagner's death mask, with hills and valleys being nothing but wrinkles in Wagner's face. So vast are its dimensions that the nostrils serve as Kundry's cave.

Reference to Wagner is not coincidental here: like few other composers, Wagner's name is associated with expanding the temporal dimension of music. The Wagnerian aesthetician Arthur Seidl makes an extended case for Wagner's music transcending the rhythmic dimension and leaving behind music that is based on a tactus or regular pulse. Seidl, who does not distinguish very strictly between rhythm and meter, considers this "a-metric"36 quality to be the true sublime in music: "The more rhythm (in a stricter as well as in a narrower sense) retreats, indeed disappears, the sooner this 'musically sublime' will break through as the ultimate, innermost core of musical art." ${ }^{37}$ Although the kind of sounds heard in the Halberstadt John Cage Organ Project doubtless go far beyond what Seidl imagined in his nineteenth-century musical and philosophical framework, as we shall see, his conception of the musically sublime as something "a-metric" can be fruitfully applied to

\footnotetext{
${ }^{35}$ Hans Jürgen Syberberg and Richard Wagner, Parsifal (Germany: Gaumont/TMS Film, 1982). ${ }^{36}$ Seidl, 126.

${ }^{37}$ Arthur Seidl, Vom Musikalisch-Erhabenen (Leipzig: C. F. Kahnt, 1887), 123. Kiene Brillenburg Wurth has recently provided what is the most thorough reconsideration of Seidl in English, see her Musically Sublime, chs. 3 and 4.
} 
our questions here. Before we return to this question, let us turn to the second piece of slow music under consideration here.

\section{9 Beet Stretch}

Leif Inge, a Norwegian "ideas-based artist," as he calls himself, produced the "9 Beet Stretch" in 2002. Using a commercial recording of Beethoven's Ninth Symphony, Inge manipulated the sound by stretching out the music so as to last a whole twenty-four hours. The pitches of the original recording are preserved; it is merely the temporal axis of the music that has been stretched to this new extent.

The idea of using a CD recording of Beethoven Nine to fill out the whole span of a day is not arbitrary: the length of a CD of roughly 75 minutes' playtime was originally determined so as to comfortably accommodate Beethoven's Ninth Symphony, which on an LP had always been fitted awkwardly on to three record sides. ${ }^{38}$ In that sense, the length of Beethoven Nine is just another temporal unit that is in common usage, just as the 24 hours that make up a day. Moreover, the recording chosen—a readily available CD from the low-price Naxos label with the Hungarian conductor Béla Drahos and the Nikolaus Esterházy Sinfonia and Chorus dating from $1996^{39}$-ensures that the association with a famous orchestra or conductor is minimized. This is not Toscanini's or Karajan's Ninth-its "workness," the

\footnotetext{
38 This is a slight simplification: the playtime of the CD was extended a little after the first prototypes, from 60 mins to 74 mins, following a suggestion by Sony's vice president Norio Ohga, so as to accommodate Wilhelm Furtwängler's 1951 recording of Beethoven's Ninth Symphony. This famous anecdote is recalled in all histories of the CD, see < http://www.dutchaudioclassics.nl/The_cd_laser/>, accessed February 21, 2012.

${ }^{39}$ Beethoven, Symphony No. 9 (Hong Kong: Naxos, 1996).
} 
iconicity of its interpretation, is minimized. For Inge, it is merely the material on which his sound installation is based, and as such it is eminently replaceable, as he emphasizes.

At the same time, while the recording might be deliberately understated and as good as anonymous, the choice of Beethoven's Ninth is not: the symphony is generally agreed to occupy the most central position in the classical canon. Stretching its length to last 24 hours - to a length that exceeds our concentration span to an uncomfortable extent-is to give manifest expression in the temporal domain to the perceived magnitude, the inner greatness, or indeed the monumentality of this work. Simultaneously, it can be argued, the stretched-out version also emphatically denies this all-too-familiar piece its traditional work character and forces its listeners to encounter the piece afresh, from a changed temporal perspective. Inge has played this piece of sound art in a number of spaces, and it is also available online, as a live-stream that is on permanent loop. ${ }^{40}$ It seems that, according to Inge, Beethoven's Ninth Symphony shares this canonical position with Mozart's Requiem: he encourages the production of similarly monumental stretched-out works using other recordings and, he adds tongue-in-cheek, if no recording of Beethoven Nine is ready-to-hand, Mozart's Requiem should be used instead. ${ }^{41}$

What is most striking when listening to the music at this extremely slow speeddecelerated by a factor of 22.15-is the changed perspective on the music. Relatively

40 The beginning of the piece is daily at 8:15pm local time in Vienna (i.e. Central European Time). As Inge explains, this was the time when the first performance began. <http://www.expandedfield.net/>, accessed on October 1, 2010.

41 Unbeknown to Inge, it was not Mozart's Requiem but rather a slowed-down version of Justin Bieber's song "U Smile," that became an internet sensation in the summer of 2010. http://soundcloud.com/shamantis/j-biebz-u-smile-800-slower accessed on October 1, 2010. 
speaking, 9 Beet Stretch is much faster than the Halberstadt John Cage Organ Project, by orders of magnitude: even if we just dip into the musical stream for a short time at random, we will most likely still hear a succession of sonic events. Yet, the listener is hard pressed to recognize the original piece: it lacks meaningful rhythmic relations, phrases are no longer coherent, cadences have lost their shaping force, and melodies are barely perceptible as cogent entities. What we hear, quite literally at the limen of aurality, are sounds that are best described as ambient and that seem to have only a distant connection to the timbre of the instruments that originally produced them..$^{42}$

Most strikingly, when played at this slow speed what emerges from the recording is that the changes between sonorities are rarely clean breaks. Rather, the new and old sonorities frequently overlap with the result that grating dissonances are produced-and sustained for several seconds—-that had been all but inaudible at the regular tempo of the performance. (It would be wrong to fault the orchestra in the recording Inge is using for this effect. Rather, in a full symphony orchestra those minute inaccuracies, which would be all but unnoticeable at regular speed, are simply inevitable. ${ }^{43}$ There is a new level of dissonance in the piece that had lain dormant in the music until it was slowed down. The real interest in this piece lies in the music that is made in the interstices.

\footnotetext{
42 This effect is common: the initial fluctuations during the attack are critical in the recognition of instrumental timbres. Where these initial microseconds are missing or distorted, timbral recognition is greatly impeded.

${ }^{43}$ Moreover, these new dissonances that emerge in the slowed-down version may also be augmented by the Fast-Fourier-Transform (FFT) technology applied to "stretch" out the data stream. If a temporal unit falls on or across a change of sonorities this moment will invariably be highlighted as one of such dissonances.
} 
The idea that a deceleration of events will lead to a new perspective and different focus is one that was explored in the field of literature in Sten Nadolny's novel, The Discovery of Slowness (1983), from which this paper borrows its title. The historical novel is based on the life of John Franklin (1786-1847), a British naval officer and polar explorer. In Nadolny's novel, and in deviation from reality, the hero's character is marked by exceptional slowness-a quality that would increasingly come to be regarded as a handicap as the Industrial Revolution progressed. Nadolny's John Franklin, however, quickly learns that his slowness is not necessarily detrimental: it goes hand-in-hand with other qualities that are lost as a consequence of Western societies turning towards acceleration: Franklin is exceptionally tenacious, thorough, and he takes the time to think through situations. This combination of slowness and tenacity that constitutes a special and unique strength is foregrounded right from the beginning of the book, describing Franklin's childhood:

John Franklin was ten years old, and he was still so slow that he couldn't catch a ball. He held the rope for others. It reached from the lowest branch of the tree to his upraised hand. He held it as firmly as the tree, and he didn't drop his arm until the end of the game. He was suited to be a rope holder as no other child in Spilsby, or even in all Lincolnshire. The clerk looked over from the Town Hall. His glance seemed approving. Perhaps there was no one in all of England who could stand still for more than an hour and hold a rope. He stood quietly, like a cross on a grave, towering like a statue. ${ }^{44}$

${ }^{44}$ Sten Nadolny, tr. Ralph Freedman, The Discovery of Slowness (New York: Viking Penguin, 1987), p. 3. 
Later on in the novel, Franklin's characteristic slowness-coupled with the concomitant ability to step back, take time, and focus on the details—-become more prominent. It is thanks to his unique slowness, paradoxically, that Franklin is able to analyze and solve major problems, where his faster contemporaries have failed.

The parallels to 9 Beet Stretch are not hard to fathom: where Nadolny's novel makes the connection between slowness and attention to detail as compensatory mechanisms, Inge's 9 Beet Stretch suggests an intimate causal link between both: as the tempo of the music slows down, the previously inaudible dissonances automatically move to the center of our attention. The liminal deceleration of the music cannot help but bring the details into focus.

So far it seems fair to say that what we are dealing with here are two pieces that are extremely slow. Beyond this fundamental similarity, however, the commonalities seem to disappear. The two pieces are very different in many ways, and the questions that we derive from them are, apparently, different as well. The Halberstadt Cage Project challenges our attention span with its long stretches of uneventful sustained sounds, whereas in the 9 Beet Stretch the attention shifts from the notes of the score to what happens between them in performance. What is the common ground between the two slow pieces? How are we to understand these pieces, how to listen to them? What do these extreme projects tell us about the aural world around us? 


\section{Time Axis Manipulation}

Like Nadolny's novel, projects like the Halberstadt John Cage Organ Project and 9 Beet Stretch have been read-justifiably so-as critiques of the hectic pace of modern life. ${ }^{45}$ But is the idea of extreme slowness, slowness that exceeds the level of comprehension, really a wholly new idea? In fact, it has been suggested that the notion of slowness in 9 Beet Stretch can be traced back to the figures often called the "first composers" in Western music history, Leoninus and Perotinus, the musicians associated with the Notre Dame repertoire of the late twelfth and early thirteenth centuries. ${ }^{46}$ Within this repertoire, it is especially the extreme durations during which the tenor syllables are sustained in the long four-part organa, Viderunt omnes and Sederunt principes, usually linked with Perotinus's name. ${ }^{47}$ According to some measurements, the notation of Viderunt omnes suggests that the first tenor note could theoretically be as long as 50 minutes, though it is wildly unlikely that such a slow speed was ever practiced in performance. ${ }^{48}$ Modern recordings choose a tempo that sustains the first tenor note for just under a minute.

\footnotetext{
45 See for instance, Ralph Kohpeiss, Sten Nadolny: Die Entdeckung der Langsamkeit. Eine Interpretation (Munich: Oldenburg, 1995).

469 Beet Stretch's affinity to Pérotin was suggested on < http://www.harsmedia.com/SoundBlog/Archief/00550.php>, accessed March 20, 2011. 47 The English theorist known as Anonymous 4 attributes these organa to Perotinus. See Fritz Reckow, ed. Der Musiktraktat des Anonymus 4, 2 vols. (Wiesbaden: Franz Steiner, 1967). For recent scholarly reflection on these questions see Edward Roesner, "Who made the Magnus liber?," Early Music History 20 (2001) , 227-266, and Jürg Stenzl, "Perotinus Magnus: Und die Musikforschung erschuf den ersten Komponisten. Nach ihrem Ebenbilde erschuf sie ihn.” Musik Konzepte: Perotinus Magnus 107 (2000), 19-49.

${ }^{48}$ See Michael Scott Cuthbert, "Changing Musical Time at the Beginning of the Renaissance (and Today)," in Renaissance Studies in Honor of Joseph Connors, edited by Louis A. Waldman and Machtelt Israëls (Firenze: Olschki, forthcoming).
} 
It may seem that this observation about twelfth-century music might rattle my initial hypothesis that slowness has something important to do with the turn from the second to the third millennium. Was slowness in fact invented, to put it somewhat hyperbolically, together with western polyphonic music? As we shall see, there are some important similarities and differences between these repertoires that can help us understand better how slowness functions on the whole, and what distinguishes slowness in the new millennium. ${ }^{49}$

While the tenor notes in Notre Dame organa, drawn from liturgical plainsong, are indeed stretched out to extreme lengths, they do not represent a slowness that we have developed here: the upper organal voices above the plainsong move in very fast rhythms; it is these rhythms that capture the attention of listeners, not the long tenor notes themselves. If the long-sustained sounds of ASLSP at Halberstadt are effectively "silent," that is, lacking a pulse of sonic events, then these long drawn-out tenor notes in Notre Dame organa are quite "noisy" in the context of the fast-moving organal voices above them. In other words, the underlying metric pulse that holds all the independent polyphonic parts together moves at quite a fast pace; the tenor parts are consequently better described as long, but not slow.

Nevertheless, it is worth considering Notre Dame organa a little longer. This repertoire is usually considered historically significant not only because it contains the earliest examples of three- and four-part polyphonic music, but also because it survives in one of

${ }^{49}$ For an introduction to the field of rhythmic notation in the medieval period, see Anna Maria Busse Berger, "The Evolution of Rhythmical Notation," in Thomas Christensen, ed., The Cambridge History of Western Music Theory (Cambridge: Cambridge University Press, 2001), 628-656. 
the earliest examples of rhythmic notation. In fact, it can be argued that the extremely long note values of the plainsong in the tenor of Notre Dame organa are predicated on a combination of these factors: First, polyphony in multiple independent parts allows the tenors of the four-part organa to be stretched out longer than any others; there is a direct correlation between number of voices and length of the tenor notes. Second, rhythmic notation fosters the complexity in which these multiple independent polyphonic voices move. And finally, a continuous metric pulse, which necessarily underlies this polyphony, ensures the coordination of the complex rhythms in all the voices. This pulse, on which the notation critically depends, becomes the beating heart of the music, holding all the parts together and allowing the tenor notes to reach for unheard-of lengths. In this interaction between length, pulse, and notation, music becomes measured, mensurata.

Despite these important conceptual differences from our millennial pieces, Notre Dame slowness has drawn our interest to the question of the medium, in this case of notation. The expansion of temporality while still retaining coherence practiced here was probably not caused, but certainly greatly facilitated, by the institution of rhythmic notation. With this thought I want to return from our short historical excursion and argue that an understanding of the media in which our two millennial pieces exist is also critical to understanding the particularities of their slowness.

One other term, a more technical one, to express the phenomenon we are grappling with is Time Axis Manipulation, or TAM. The idea of time axis manipulation was explored in detail 
in the context of Friedrich Kittler's media aesthetics, and has been highlighted as the centerpiece of his technological thinking. ${ }^{50}$ Media are defined in this context as follows:

Media are practices that use strategies of spatialization to enable one to manipulate the order of things that progress in time. Such means of time axis manipulation are only possible when the things that occupy a place in time and space are not only seen as singular events, but as reproducible data. Such production sites of data are 'discourse networks'. Discourse networks are media in the broader sense: they form networks of technological and institutional elements. ${ }^{51}$

Kittler is very interested in the workings of language, broadly conceived, writing, and techniques of data processing, but it is easy to see how the principle of Time Axis Manipulation is particularly important for the question of musical duration. Especially if we remember that one common working definition of music, and probably not the worst one, holds that it is the shaping of time by means of sounds, we can see how TAM provides a picture-perfect response to this approach to music.

The original German term Aufschreibesysteme - "writing-down systems"—has a wonderful concreteness and directness that is missing in the more abstract English translation. Because that is precisely what an Aufschreibesystem is: it is, in the first place, a way of notating a data stream that makes it storable, reproducible, and manipulable. ${ }^{52}$ As we saw, the rhythmic notation of the twelfth century provided one such Aufschreibesystem, in a very

\footnotetext{
${ }^{50}$ Sibylle Krämer, "The Cultural Techniques of Time Axis Manipulation: On Friedrich Kittler's Conception of Media," Theory, Culture and Society 23 (2006), 93-109. ${ }^{51}$ Ibid. 106.

52 See Friedrich Kittler, Discourse Networks (Stanford: Stanford University Press, 1990).
} 
literal sense, where the temporal dimension came to be captured on paper and became a function of the coordinated rhythmic notation.

In this way of thinking the transition from hand-written manuscripts to printed books at the turn of the sixteenth century - the emergence of the "Gutenberg galaxy"53_is not terribly relevant, since it does not change the technical capacities and limitations of the medium in any major way. Kittler is concerned much more about such events as the change from the continuous text of the scrolls of the torah to the division of pages of the Christian bible. ${ }^{54}$ (One might wonder whether the change from partbooks to score notation would mark a similarly decisive medial shift in the field of musical Aufschreibesysteme.)

The crucial date as far as the mediality of sound is concerned is 1877, when Edison invented the phonograph. ${ }^{55}$ As Kittler has argued at length, Edison's phonograph marked a decisive step in the history of media because from then on it was not just notes that could be stored and reproduced but sounds themselves. What was being written down and captured on record now was the soundwave itself. ${ }^{56}$ As has been pointed out repeatedly,

53 While Kittler is at pains to set himself off from McLuhan's ideas-especially that of media as extensions of the human body-it is hard to deny that he is not also indebted to certain of McLuhan's ideas.

54 See Krämer, “Cultural Techniques,” 100. (As often, Kittler exaggerates his claims somewhat. The split into rolls and codices does not follow religious traditions quite as neatly as Kittler's argument suggests. See Colin Henderson Roberts, "The Codex", Proceedings of the British Academy 40 (1954), 169-204. I am grateful to Thomas F. Kelly for pointing this out to me.)

${ }^{55}$ And, as always, in such momentous events, it is only a form of shorthand to pinpoint an exact moment. Lisa Gitelman and others have vigorously criticized Kittler for his tendency to overstate his case in the search for snappy one-liners, see Gitelman, Scripts, Grooves, and Writing Machines: Representing Technology in the Edison Era (Stanford: Stanford University Press, 1999).

56 For the musicological implications of this technique, see David Trippett, "Composing Time: Zeno's Arrow, Hindemith's Erinnerung, and Satie's Instantanéisme," Journal of 
the sonic Aufschreibesystem that was used to capture sounds is no longer decipherable by the naked eye. It can only be felt by the stylus of the gramophone player, and converted back into sounds by mechanical means. At the same time, as Edison and others were eager to show, the new technology allowed new mechanisms of manipulating the data: it could be speeded up or slowed down in a way that had not been possible with "live" music. ${ }^{57}$

One technological problem, however, remained, and has remained a problem until relatively recently: the physical dimension to which our perception of pitch corresponds is based on frequency-and therefore a temporal function. Pitch and rhythm are both coded as temporal dimensions on the sound wave. ${ }^{58}$ If we slow down the speed at which the record plays, we also slow down the rate of oscillation that determines the pitch content. That is why it was impossible to manipulate the speed of a recording without affecting the pitch content at the same time. It invariably becomes fast Mickey Mouse or slow voice from beyond the grave, but never slow Mickey Mouse and fast voice from beyond the grave.

Steve Reich was one of the composers who had long been fascinated by the idea of slowing down recorded sounds. He captured this idea in his composition Slow Motion Sound (1967), which merely consists of the instruction to slow down recorded sound while retaining the original pitch levels. The piece remained unperformed, partly because it was part of a

Musicology 24 (2007), 522-580, and Alexander Rehding, "Wax Cylinder Revolutions," Musical Quarterly 88 (2005), 123-160.

57 The whole notion of "live" music, of course, only comes into being as soon as recorded playings are given their own status as a normal mode of existence of music.

58 I have explored issue this further in "On Sirens Old and New," The Oxford Handbook of Mobile Music, ed. Sumanth Gobinath and Jason Stanyek (New York: Oxford University Press, forthcoming). 
movement within conceptual art where the instruction to create the work simultaneously constituted it, and partly because the technology to achieve this effect did not exist.

Technically, the correlation is still impossible to cut through. But in our own digital age, computer technology has made it possible at least to simulate a division between the temporal dimension and the (apparently atemporal) pitch dimension. This is precisely what Inge's 9 Beet Stretch is based on, and the mechanism that he highlights as "temporal manipulation that does not affect pitch content." Strictly speaking, Inge is somewhat oversimplifying the situation: a more precise description would be to call it a temporal manipulation with pitch adjustment and correction. But for all intents and purposes, the

technology that Inge's work is based on-Fast Fourier Transform—has effectively severed the connection between the temporal aspect of sonic frequency, and the temporality of sound duration.

\section{Stretching time}

The critical difference in the two millennial pieces with which we started-9 Beet Stretch and $\operatorname{Organ}^{2} / A S L S P$ - and the examples from the previous millennium of music history is that these two pieces no longer employ a human performer. This is not just an incidental feature, but gives us an opening towards understanding how these pieces work, crossing over, as they do, into a dimension where conventional listening regimes break down.

On the surface the strategies both pieces employ seem different: one manipulates a recording, while the other piece is still performed by mechanical means. But across these 
differences, both pieces are no longer under the control of one human performer; they no longer rely on an individual's sense of pulse and experiential time in human dimensions to keep the piece hanging together. ${ }^{59}$ We can quibble about whether any two individuals really hear in exactly the same way or not, and by extension, to what extent a performer's perception of time and that of a listener really match up. But it seems safe in any case to make these generalizations in the face of the vast temporal dimensions presented here. ${ }^{60}$

It is here, in the vastness of dimensions and the disproportionality to human perception, that the question of the sublime that I invoked at various stages in this essay, comes to the fore. The rise of the aesthetic prestige of music in the course of nineteenth century among the arts, and especially as the art of the sublime, can be explained with reference to its radical temporal nature. ${ }^{61}$

Whether we base the sublime on Sulzer's early version—as an "empirical symbol," a "yardstick"-or on the more intricate versions of German Idealism, the idea of music unfolding over time resonates with the fundamental insight that the concept of selfhood is based in temporality. This is a point that connected even the great antagonists Hegel and Schopenhauer. In Hegel's poetic description:

${ }^{59}$ I shall leave out here the possibility of counting the person hanging the weights on the organ keys during $A S L S P$ as the "performer."

${ }^{60}$ The broader cognitive question that is being raised by all these works, albeit in different ways, is this: when do we stop perceiving a melody as a melody, or a phrase like a phrase, and what purpose does it serve to go beyond these thresholds? Music perception has long been interested in questions of this nature, and different experiments have led to different results. See, for instance, Richard M Warren, Daniel A Gardner, Bradley S Brubaker and James A Bashford Jr, "Melodic and Nonmelodic Sequences of Tones: Effects of Duration on Perception," Music Perception 8:3 (Spring 1991), 277-290.

${ }^{61}$ See Kittler, "Musik als Medium," in Bernhard J. Dotzler and Ernst Martin Müller, ed., Wahrnehmung und Geschichte. Markierungen zur Aisthesis materialis. (Berlin: Akademie Verlag. 1995), 83-99. 
"I" is in time, and time is the being of the subject itself. Now, since time and not space as such constitutes the essential element in which the tone, with respect to its musical significance, gains its existence and the time of the tone is simultaneously that of the subject, the tone itself enters into the self on this very basis, grasps the self on the basis of its simplest existence and sets the "I" in motion by means of temporal motion and its rhythm. ${ }^{62}$

The short addition "with respect to its musical significance" is critical because, we remember, Hegel saw the quick disappearance of individual tones as a problem. It is for this reason that Idealist thought latched on to the abstract musical work, of which individual performances were a representation. In a word, music became a metaphor for selfhood.

But what of the sublime? This is where Arthur Seidl's Schopenhauerian perspective on the question of identity and music comes to the fore:

Following its very own character, it lifts up the human from the individual world of appearances, beyond the limits of earthly, merely natural existence. But it also teaches us another thing: with the tone only moving, for us, in the one-dimensional perspective of time, it reveals itself (like our "Will," which merely touches the individual sphere in the one-dimensional perspective of time and therefore touches the "thing-in-itself"

${ }^{62}$ Hegel, Ästhetik, III: 156-157. “Ich ist in der Zeit, und die Zeit ist das Sein des Subjekts selber. Da nun die Zeit und nicht die Räumlichkeit als solche das wesentliche Element abgibt, in welchem der Ton in Rücksicht auf seine musikalische Geltung Existenz gewinnt und die Zeit des Tons zugleich die des Subjekts ist, so dringt der Ton schon dieser Grundlage nach in das Selbst ein, faßt dasselbe seinem einfachsten Dasein nach und setzt das Ich durch die zeitliche Bewegung und deren Rhythmus in Bewegung." See Kittler, "Musik als Medium," 90. 
most immediately) as so closely related to the inner core of all appearances and as so much part of the essence of things that it enables us to grasp this inner core through it [the tone] in its most immediate manifestation. ${ }^{63}$

It is not difficult to see how Seidl's perspective is pertinent for our case. The very slow millennial pieces here are not mere representations (that is, performed instantiations of musical works, which could be contained because of their relatively short temporal span), but they become the musical object itself. Identification here no longer operates on the metaphorical level, but the subject is confronted with the realization that the music will be going on for much longer than the life span of the subject itself. The subject is forced, true to the Idealist tradition of the sublime, to confront its own finitude and will, after a process of reflection, emerge victorious and strengthened. And as we saw earlier in Michael Chabon's euphoric affirmation of humanity in the face of the "Clock of the Long Now," subjects may ultimately garner fortitude from considering their own insignificance when compared with (near) infinity.

The way toward this affirmation of selfhood as the result of the experience of the sublime, according to the Idealist philosophers-though not Lyotard's postmodern sublime-must happen by employing the instruments of reason. The individual must resist the awesome

\footnotetext{
${ }^{63}$ Seidl, Vom Musikalisch-Erhabenen, 116-117. "Nach ihrem eigensten Charakter hebt sie den Menschen aus der individuellen Erscheinungswelt empor, sofort über die Grenzen beschränkt irdischen, rein natürlichen Daseins hinaus. Aber auch noch ein anderes lehrt sie uns. Indem nemlich der Ton für unsere Auffassung gänzlich nur in der eindimensionalen Anschauungsform der Zeit sich bewegt, zeigt er sich (ähnlich wie unser die individuelle Sphäre auch nur mehr in der eindimensionalen Anschauungsform der Zeit streifende und [117] dadurch das 'Ding an sich' am unmittelbarsten berührende 'Wille') dem Innern aller Erscheinung so nahe verwandt und des Wesens der Dinge in einer Weise teilhaftig, dass er uns befähigt, dasselbe durch ihn in seiner unmittelbarsten Kundgebung zu erfassen."
} 
magnitude of the object and extricate himself or herself from the overtaxed senses and somehow capture the object in its totality, even where its nature forcefully resists such objectification. This is where the spatial dimension steps in. Seidl continues his explanations, following on immediately from the excerpt quoted above:

It is only in the external symmetry of rhythm (that is, of the temporal element) that this universe converges again with the spatial world [dem Plastischen], this "in-itself" returns at least partly to the realm of external appearances-and it does so in close analogy to the way the perspective of time ties the primordial and all-encompassing Will, which originally and essentially exists outside of time and space, back to the laws of the intellect, that is, to the world of representations. ${ }^{64}$

As we saw before, Seidl's aesthetics of the sublime of music is predicated on distinction of spatiality (or das Plastische—-which can perhaps best be rendered as "threedimensionality") and temporality. Rhythmic or metric regularities, for him, will always lead back to a spatialized concept of music that is, in Seidl's understanding, not in itself sublime. ${ }^{65}$ In order to become truly sublime, Seidl asserts, music must leave behind all spatiality—all regularity of rhythm—and become "a-metric" and purely temporal.

${ }^{64}$ Ibid. 117. "Erst in dem äusserlich Symmetrischen des Rhythmus (also des Zeitlichen) nähert sich-und zwar in ganz analoger Weise, wie die Anschuungsform der Zeit den ursprünglich und wesentlich raum- und zeitlosen Ur- und Allwillen wieder an die Gesetze des Intellektes, d.h. an die Vorstellungswelt knüpft—nähert sich also dieses All dem Plastischen, begibt sich dieses 'Ansich' wenigstens teilweise auf das Gebiet der äussern Erscheinung." ${ }^{65}$ Seidl distinguishes between the "sublime in music" and the "sublime of music": the former indicates musical signifiers of sublimity (e.g. loud fanfares, mysterious chromatic chords, rich sonorous string textures with harp arpeggios), while the latter reveals, for Seidl, the true essence and destiny of music, which he finds best realized in Wagner. 
Seidl's distinctions can be quite useful for our purposes. The spatial dimension can in fact be used to invoke a sense of the sublime and also to extricate our selves from it. Let's begin with the process of extrication: As we saw, it is only with these quasi-spatial categories that labels and order can be imposed on the sonic events, and the sound events can be "rationalized" (without necessarily subjugating our selves to reason). In his Lessons on the Analytic of the Sublime, Lyotard explains in greater detail how such a "rationalization" (or "surveying") can occur:

The imagination contents itself, one might say, with "surveying" the given magnitudes by progressive composition. The imagination will do this under the sole direction of understanding; it can rest assured that understanding will not ask it to grasp "in a glance" [in einem Augenblick] all the units that compose these magnitudes. Thought will thus remain confined in the recurrent mathematical synthesis of a series that can be infinite. 66

What Lyotard is describing here is Kant's mechanism that would allow the self to resist the "almost-too-great" quality of the sublime by a process of re-spatialization: the imagination retreats into purely measuring the quantities it is confronted with. In this way, the self effectively intellectualizes the experience and evades a direct engagement with the overwhelming sensuous totality.

Such a process is always possible with both pieces in question: we can always rationalize away the unchanging sounding silence of the organ sounds in Halberstadt or the unheard-

${ }^{66}$ J.-F. Lyotard, The Analytic of the Sublime, tr. Elizabeth Rottenberg (Stanford: Stanford University Press, 1994), 138. The "in a glance" makes reference to Kant's formulation, in einem Augenblicke. 
of dissonances of 9 Beet Stretch by relating them back to the compositions from which they sprang, by "surveying" them rather than engaging them directly, by thinking of them as notes rather than hearing them as sounds, but only at the cost of experiencing their dimension as temporalities.

And at the same time, it was the spatialization of sounds that made these sublime pieces possible in the first place: In both cases a strict and consistent spatialization of the musical text was necessary to achieve these results. Let's first look at 9 Beet Stretch. As we have already seen, the score-in the sense of the notated material worked upon and manipulated-is in this case the innocuous Naxos recording of the Beethoven. The slow version is not based any more on the durational patterns of the original score that Beethoven wrote, but on the sounds conveyed in the soundwave. In other words, if a rhythm is performed inaccurately in the original recording, this inaccuracy will be blown up by a factor of 22.15 because the sounds are measured in terms of distances. A certain symbolic level remains, of course: the digital code of zeroes and ones has no dimension whatsoever, and that is the reason Kittler celebrates the digital age as the stage where his anti-Hegelian Phenomenology of Writing must end. But nonetheless, as long as we describe in words what happens here, the spatial realm is the only one available to us that provides us with terms suited to expressing the foundation of these manipulations.

In the case of Cage's $\operatorname{Organ}^{2} / A S L S P$, meanwhile, the spatial dimension has been central right from the very beginning: we remember that the time interval between two musical events is determined by the distance between two stems in the notation. The "musicking" - or "sonic processing"—of this score is therefore nothing but the temporal 
expression of these spatial distances. What's important about $\operatorname{Organ}^{2} / A S L S P$ is that the absence of a performer is not just accidental here. Let's just assume for the moment that humans could live for 639 years and that the Halberstadt performance of $\operatorname{Organ}^{2} / A S L S P$ was possible under the hands of one extremely longevous organist. It would still not be possible to represent the temporal relations of this rendition in similarly de-humanized terms. The Halberstadt performance, to put it poetically, lacks a heartbeat, and deliberately so. ${ }^{67}$

I started by tentatively suggesting that in a dimension in which temporal relations have become meaningless music seems to take on spatial attributes again. Given the spatialization of time and the manipulation of the soundwave that is so central to TAM, it seems fair to say that in a realm that normally lies beyond the reach of our experience these are the best terms we can hope for. Even though the Halberstadt performance, unlike 9 Beet Stretch, uses traditional mechanical means to stage this piece, it is conceptually cut from the same cloth as the digital artwork. The technical means may have been there in 1361, but it is a form of presentation that only makes sense in the "post-Edison galaxy," the medial possibilities of our own age, defined as they are by Time Axis Manipulation, and its possibilities of writing sound.

We remember Hegel's idea of a tone as "an existence that disappears by being." 68 What is being changed in these two pieces is no less than the philosophical definition of tone. Under the banner of Time Axis Manipulation the duration of the sound is completely uncoupled

${ }^{67}$ This is in fact exactly what Steve Reich complained about: manipulated recordings lacked the human element-slight inaccuracies and even minimally emotionally charged responses-that caused Reich to abandon his experiments with TAM in the late 1960s. ${ }^{68}$ See [fn. 20] above. 
from its decaying sonic properties, either by mechanical means, in the case of $\operatorname{Organ}^{2} / A S L S P$, or by digital means, in the case of 9 Beet Stretch. In either case, the tone is taken as a fixed duration, and the sonic content is refilled so as not to affect its pitch properties. And it seems that this reconceived sonic parameter of this very slow millennial music opens up a "second-order" spatial dimension that allows us to access this liminal aurality and to explore the music in previously unimaginable ways-by wandering around the sonic spaces of $\operatorname{Organ}^{2} / A S L S P$ or by inserting our selves into the grating dissonances of 9 Beet Stretch. 